\title{
Finding Aid, Archives as Art \& Pharmakon, Box I, Folder 16: Gabriella Giannachi's Mappings
}

\author{
Review by Craig Saper
}

Giannachi, Gabriella. Archive Everything: Mapping the Everyday. Cambridge, Mass.: MIT Press, 2016.

Archive | 'är,kīv | noun. etymology, from Greek arkheia for "public records," from arkhē for "government." The verb form dates from the late nineteenth century, but now often refers to an entire logic especially in relation to the electronic compiling of information.

Etymologically, the noun "archive," although now commonly applied to the storage place of cultural objects, had until recently a much more limited meaning applying only to government records. Most contemporary discussions of the term use the modern usage that effaces the earlier connectiol to the seat of political power. The notion of a collection, or collecting of, historical and rare materials of any kind - but usually of cultural importance - almost makes it grist for personal or aesthetic fascinations.

Since Derrida's Archive Fever, the term increasingly becomes a verb describing a Borgesian logic and paranoid intensity of the haunting of an entire weight of the archive in the reading of a supposedly singular text or original author. Gabriella Giannachi's book, Archive Everything, uses the term as verb, and suggests the mise-en-abyme paradox of the endeavor to archive everything: is the archive itself contained in this infinite archive of everything? And, if it is a yearning desire to archive wildly and madly everything which comes near you, then is it modernity's last expansive gasp to surveil, catalogue, archive, and contain everything - totalizing and abstractly - become a perversion?

To write a book review with this modern usage of archive as a method (vacillating in a liminal space between verb and noun form), one pulls the materials contiguous to the focus of the review. One might trace this usage of archive, as a place that pulsates with, or at least sets-off, visceral and aesthetic effects, to Jacques Derrida's Archive Fever. It's worth revisiting that text along with these others as they mark off something like an entirels new meta-genre or a mise-en-abymchive (a pun suggested to this reviewer by the array of over 770 thousand books with archive in the title). Writins book review of one book leads first to a group of books on archive arts and soon cannot help but lead one into a Borgesian archive of everything which is what Giannachi's provocative title promises at least, in part, even as the subtitle actually limits the scope of the book to a desire to organize artifacts of "the everyday" instead of a feverish desire to capture and contain and control infinity. Giannachi's book is an important finding aid for anyone interested in the history and evolution of archives as it moves from archive 1.0 to 2.0, 3.0, and the contemporary 4.0. That history moves frol a setting exemplified by the Vatican archive to a modern notion of a dynamic and continuously updated center of political power to a contemporary version of the archive as a collection of cultural ephemera that does not easily fit on a libraries' shelves - especially, in Giannachi's book, feminist media art projects. Although I would have perhaps foregrounded the connections among the history and theorization of a way to frame "everything" the feminist media artworks described in the main chapters of the book. The connections are hinted at simply by being contiguous, but, for exampl $\epsilon$ Lynn Hershman Leeson's projects are not mentioned in the opening sections. After the necessary methodological section with discussions of Foucault, and others - about the social organization of knowledge, Giannachi looks at art projects as indicators of contemporary cultures' archive practices as perhaps the crucial aspect of our electronic mediated culture. So, a reader might expect a book more like Spieker's study, cited below, instead of placing Giannachi's study in the context of the feminist media projects that is the real added value of Giannachi's book. This review might suggest that the feminist media art projects, and other experiments, offer a collectivist and feminist reframing of individual achievement. These othe artworks haunt or reverberate with the archive - unlike the modernist myth of the originality and singularity of the individual (male) artist. It is that myth that Leeson's project, and others discussed in Giannachi's book, convincingly debunk and suggest another way to think of media artworks outside of the absurd idea of working outside the catalogue of a collective vision. What the book could make clearer and up front in the opening of $i$ whether that feminist media arts perspective also is inherent in archives read back into its history. The study does start a study of the use of (the) archive as an important aspect of works by Marcel Duchamp, Robert Morris, and the art-collective Ant Farm, ReConstitution, Daniel Libeskind's Ber Jewish Museum, and the transmedia works of sosolimited, but these are used to support the main focus on feminist art experiments. The discussio of Lynn Hershman Leeson's hybrid media installation, The Infinity Engine, 2005-2015, and Hershman's !Women Art Revolution seem the core of the feminist aspects of archive art (or perhaps the archive as an aspect of feminism). She supports this study of the feminist media arts with discussions of the iWAR Movement, the Guerrila Girls' work, and Judy Chicago's collective and up-front archiving and citing of a created lineage of feminist art. my contention is correct, then one could imagine a book called The Use of Archive Practices in Feminist Media Arts. It would, then, draw on a somewhat different archive and audience including scholars of gender and women's studies.

To be fair, if we were to do archive art its due, then we would have to include a series of reviews in our finding aid among the seven hundred and seventy thousand published sources on archives. We would need entire boxes of reviews of specific works. In that way, we might begin with Carolyı Steedman's Dust: The Archive and Cultural History and move to Maja Kominko's From Dust to Digital: Ten Years of the Endangered Archives Programme, and jump from there to the collectively produced Dante Gabriel Rossetti: A Hypermedia Archive and shuffle through Cornelia Vismann's Files, and certainly include Trevor Owen's Library of Congress blogpost on "What Do You Mean by Archive? Genres of Usage for Digital Preservers,' and then we might have a separate box for just the recent archive-art histories with folders on Sven Spieker's The Big Archive: Art From Bureaucrac. 
(also published by MIT - suggesting an entire series in this area), Okwui Enwezor's Archive Fever: Uses of the Document in Contemporary Art (an excellent exhibit catalogue on a survey of contemporary archive-art), and perhaps in mise-en-abyme style a folder with this modest review of Giannachi's book. One might include works on archive as a verb and a method in the artworld; in that case Jeremy Braddock's Collecting as Modernist Practice and Theis Vallø Madsen's dissertation on Ants in the Archive (which you can find at Aarhus University, Denmark) would be essen as archiving tools.

The archive would also have to include the reviews of the book, for example, Zilberg's rave review that argues that ... "appeal primarily to artists, art theorists, and academics interested in archival methodologies" Peterson's and Maceviciute's reviews from, and for, archivists rather than media art theorists, of Giannachi's study of "memory institutions," which, for Maceviciute "All of us can participate in interpretation of these modern holdings and documents as artists and citizens, as historians and creators of 'multiple presents.' The perspective of art creator is the dominating one in the book." Peterson finds the books claim that art practices influence, or even presciently foretell, contemporary cultural practices, like autobiographica social media, "dubious" and often "strains credulity." The issue that Peterson raises is specifically targeted at the book as art history - instead of library and information science. In fact, the title picks up readers from library and information studies, but perhaps loses some in the intended audience of media and performance arts historians and theorists. Media and the arts move faster than those disciplines, and Giannachi senses that the archive art is out in front of the scholarly curve; one would hope, perhaps in vain, that universities would adopt archive art programs and departments. But, precisely because the word archive is in the domain of library science, as at least a couple of the book reviews betray, or understood in digital humanities or cyber-science as merely the mining of massive stores of information into data points and the algorithmic quantification of text analytics, it seems unlikely that this emergent field (maybe the meta-disciplinary practice) will push out from under the weight o traditional types of art (i.e., 2d, 3d, and time-based) as a new category that might include what I've called "intimate bureaucracies" - or in this case DIY archive everything.

Inevitably, to archive everything is a crucial motivation and theme in the contemporary arts even if ultimately an asymptotic illness with the only medicine to archive endlessly. Making this seemingly small task of a book review of a single book - and the book title's promise - on-going. Giannachi seems to echo Francesco Berardi's line from Futurability, by the start of the twenty first century, "modern humanism proved unable to co with the networked Infosphere," and, paradoxically, the old fashioned word, in a new 4.0 iteration, might suggest a new emergent knowledge and system of future higher education. You better bring your (perhaps virtual) archive's "readers" card, and Giannachi's finding aid for navigating emergir e-media literacy.

\section{Cite this Review}

https://doi.org/10.20415/rhiz/034.r05

RHIZOMES ISSN 1555-9998 $\star 230$ East Hall Bowling Green State University Bowling Green, OH 43403

Editors: Ellen Berry and Carol Siegel. Reviews editor: Craig J. Saper. Technical editor: Helen J Burgess 